\title{
Predictors of Insulin Resistance in Obesity and Type 2 Diabetes Mellitus - The Role of Magnesium
}

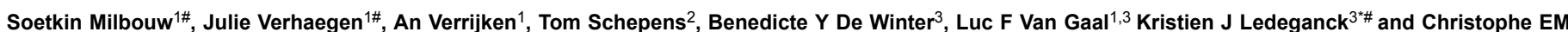
De Block ${ }^{1,3 \#}$

${ }^{1}$ Department of Endocrinology, Diabetology and Metabolic disease of the Antwerp University Hospital, Wilrijkstraat 10, 2650 Edegem, Belgium

${ }^{2}$ Department of Anesthesiology and Critical Care Medicine, Antwerp University Hospital, University of Antwerp, Edegem, Belgium

${ }^{3}$ Laboratory of experimental medicine and pediatrics, University of Antwerp, Antwerp, Belgium

"Corresponding author: Kristien Ledeganck, University of Antwerp, Universiteitsplein 1, T3.34, 2610 Antwerp, Belgium, Tel: 0032(0)32652573; E-mail: kristien.ledeganck@uantwerp.be

\#These authors contributed equally

Received date: November 21, 2017; Accepted date: November 27, 2017; Published date: December 18, 2017

Copyright: (c) 2017 Milbouw S, et al. This is an open-access article distributed under the terms of the creative commons attribution license, which permits unrestricted use, distribution, and reproduction in any medium, provided the original author and source are credited.

\section{Abstract}

Objectives: Hypomagnesaemia and insulin resistance are two major clinical problems, with intertwining pathophysiology. We aimed to explore this association in obese patients and in non-insulin-treated patients with type 2 diabetes mellitus (T2DM).

Methods: Subjects were recruited from the outpatient diabetes/obesity clinic of the Antwerp University Hospital. The population ( $\mathrm{N}=2731)$ consists of 2 subject groups with different degrees of insulin resistance and insulin secretory potential: 1 ) overweight (Body Mass index (BMI) $\geq 25 \mathrm{~kg} / \mathrm{m}^{2}$ and $<30 \mathrm{~kg} / \mathrm{m}^{2}$ ) and obese $\left(\mathrm{BMI} \geq 30 \mathrm{~kg} / \mathrm{m}^{2}\right.$ ) subjects, 2) adult T2DM patients. Hypomagnesaemia was defined as serum magnesium $<1.7 \mathrm{mg} / \mathrm{dl}$. Insulin resistance was estimated using the Homeostasis model assessment (HOMA-IR; cut-off point 2.82).

Results: Hypomagnesaemia was present in $6.1 \%$ of the entire population. Patients with hypomagnesaemia had more visceral adipose tissue (VAT), and a higher HOMA-IR. They suffered more from the metabolic syndrome and T2DM. Patients with a HOMA-IR<2.82 were younger, had lower BMI and less VAT. They suffered less from hypomagnesaemia. Hypomagnesaemia was more prevalent in T2DM patients than in obese subjects without T2DM. Although serum magnesium and HOMA-IR were negatively correlated, logistic regression analysis showed that magnesium was not a significant predictor for HOMA-IR.

Conclusions: Despite a significant negative correlation between magnesium and HOMA-IR, magnesium was not retained as a significant determinant of insulin resistance compared to the other predictors in our population of obese subjects and T2DM patients.

Keywords Hypomagnesaemia; Insulin resistance; Visceral adipose tissue; Obesity; Diabetes mellitus; HOMA-IR; Predictors

\section{Introduction}

Insulin resistance (IR) and hypomagnesaemia are two major clinical problems. Worldwide 200 million people suffer from IR and $40 \%$ of these patients will develop type 2 diabetes mellitus (T2DM) [1]. It is estimated that by 2030, diabetes mellitus will be the 7 th most important cause of death worldwide. Moreover, the treatment of T2DM and its complications amount to $5.8 \%$ of the total expenditure of health care costs in Europe [2-4]. Research is therefore essential to investigate how the evolution of IR to full-blown T2DM can be interrupted. Supplementation of magnesium has been suggested as one potential approach [5].

The extent of hypomagnesaemia is often underestimated. The incidence of hypomagnesaemia in in-hospital patients amounts to $12 \%$, and even rises to $60-65 \%$ in patients at the intensive care unit, mostly due to a poor nutritional status, medication or hypoalbuminemia [6-8]. Also in the healthy population there seems to be a tendency of magnesium depletion due to the increased consumption of refined foods and the decreased consumption of green vegetables $[9,10]$. Most cases of hypomagnesaemia in clinical practice are asymptomatic. The clinical manifestation may depend more on the total body the $\mathrm{Mg}^{2+}$ deficit rather than on the actual serum $\mathrm{Mg}$ level [11]. Personality changes, muscle weakness, tremor and dysphagia may occur at concentrations of $<1.45 \mathrm{mg} / \mathrm{dl}$, while confusion and a decreased consciousness develop at concentrations of $\leq 1.00 \mathrm{mg} / \mathrm{dl}$ [12].

There are important interfaces between magnesium and IR as magnesium is an essential co-factor in the ATP-associated reactions on which the mechanism of the insulin receptor depends [13]. Small-scale fundamental studies have shown that $\mathrm{Mg}^{2+}$ is essential for the insulin receptor phosphorylation, but the effect of $\mathrm{Mg}^{2+}$ on the downstream targets in the muscle, liver, and adipocytes is largely unknown. Moreover, a hypomagnesaemic state leads to an increase in proinflammatory cytokines that induce on their turn inflammation of the visceral adipose tissue (VAT) in obese patients [14-16]. This inflammation might contribute to the onset of IR [14,17]. The prevalence of hypomagnesemia in T2DM has been reported to range 
Citation: $\quad$ Milbouw S, Verhaegen J, Verrijken A, Schepens T, de Winter BY, et al. (2017) Predictors of Insulin Resistance in Obesity and Type 2 Diabetes Mellitus - The Role of Magnesium. J Metabolic Synd 6: 235. doi:10.4172/2167-0943.1000235

Page 2 of 9

between 14 and $48 \%$, meaning that millions of people worldwide are affected [18-20]. In DM patients, magnesium deficiency is associated with the development of micro- and macrovascular complications [21-24]. A few papers have been published that specifically investigated the role of magnesium deficiency in the emergence of insulin resistance. Some papers confirmed a causative role for magnesium deficiency [25,26] and others did not find any associations [23,27]. Most studies were performed in rather small populations.

The aim of the present study was first to investigate the association between hypomagnesaemia and IR in a large group of wellcharacterized subjects with different degrees of IR and insulin secretory potential. Second, we aimed to investigate by means of a multivariate analysis if hypomagnesemia might serve as an independent risk factor for IR and third, to define a cut-off value for the homeostatic model assessment for insulin resistance (HOMA-IR) in a Western population as there is no consensus to define a cut-off value worldwide and HOMA-IR among others depends on race [28-30].

\section{Materials and Methods}

\section{Subjects}

The population consists of two prospectively recruited subject groups with different degrees of IR and insulin secretory potential from the department of Endocrinology, Diabetology and Metabolic diseases in the Antwerp University Hospital (a tertiary referral facility). For the current study, the collected data were retrospectively analyzed. All procedures followed were approved by the Ethics Committee of the Antwerp University Hospital $[1,10,32]$ and were conducted in accordance with the Helsinki Declaration of 1975, as revised in 2008. Informed consent was obtained from all patients for being included in the study.

The first database contains data of patients presenting with overweight (body mass index (BMI) $25-30 \mathrm{~kg} / \mathrm{m}^{2}$ ) or obesity (BMI $\geq$ $30 \mathrm{~kg} / \mathrm{m}^{2}$ ) at an outpatient obesity clinic.

Patients consulted the clinic at their own initiative or they were referred by their treating family physician. Every patient underwent a standard metabolic work-up. Patients were $\geq 18$ years. At their enrolment, patients were not involved in a weight management program. Glucose tolerance status was defined based on the criteria of the American Diabetes Association [31].

The second database contains data of adult T2DM subjects $(>18$ years old) with disease duration of at least 2 years. As glucose lowering therapy they were only treated with metformin and/or sulfonylurea.

A total of 2731 obese and/or T2DM patients were included. The flowchart for patient inclusion is shown in Figure 1.

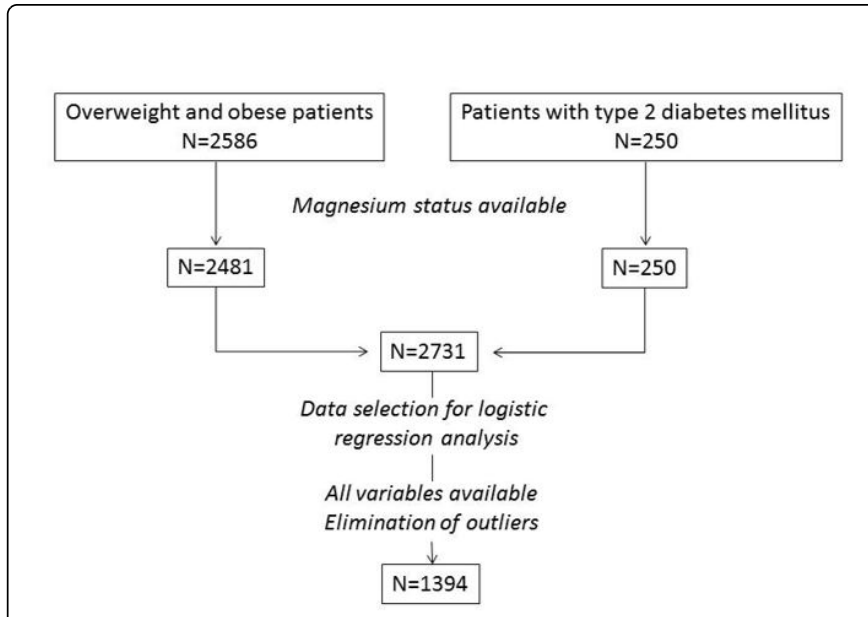

Figure 1: Flowchart of the included patients. Data selection for logistic regression analysis was based 4 on following criteria: factors had to be determined in at least $50 \%$ of the population and only 5 parameters that significantly differed between both groups were withheld.

\section{Patient parameters}

The following parameters were retrieved from the medical records in our study design: ethnicity, gender, age, anthropometric measures including measurement of visceral and subcutaneous adipose tissue by computed tomography (CT), plasma and urine standard biochemical tests, hormonal assessment, glucose status using oral glucose tolerance test (OGTT) and glycated hemoglobin (HbAlc).

\section{Definitions}

Magnesium: Hypomagnesaemia was defined as a serum magnesium concentration $<1.7 \mathrm{mg} / \mathrm{dl}$ [32-35]. The fractional excretion of magnesium $\left(\mathrm{FE} \mathrm{Mg}^{2+}\right.$ ) was computed using the following equation: $(100 \times[$ Magnesium in urine $(\mathrm{mg} / \mathrm{d}) \times$ serum creatinine $(\mathrm{mg} / \mathrm{dl})] /[(0.7$ $\times$ serum magnesium $(\mathrm{mg} / \mathrm{dl})) \times$ creatinine in urine $(\mathrm{mg} / \mathrm{d})]][6,36,37]$.

Metabolic syndrome: Metabolic syndrome was defined by the criteria from the HARMONIZING study by Alberti et al.: 1) elevated triglycerides $(>150 \mathrm{mg} / \mathrm{dL})$ or drug treatment for elevated triglycerides, 2) reduced high density lipoprotein (HDL) $(<40 \mathrm{mg} / \mathrm{dL}$ in males or $<50 \mathrm{mg} / \mathrm{dL}$ in females) or drug treatment for reduced HDL, 3) elevated blood pressure (BP) $(>130 / 85 \mathrm{mmHg})$ or antihypertensive drug treatment, 4) elevated fasting glucose $(>100 \mathrm{mg} / \mathrm{dL})$ or drug treatment for elevated fasting glucose and 5) elevated waist circumference ( $>94$ $\mathrm{cm}$ in Caucasian males or $>80 \mathrm{~cm}$ in Caucasian females) [38] Patients with an elevated waist circumference and $>2$ other criteria were considered to have metabolic syndrome [39].

Diabetes Mellitus: T2DM was defined by the criteria from the American Diabetes Association Classification, more precisely a fasting glucose $>126 \mathrm{mg} / \mathrm{dL}$ and/or a $\mathrm{HbAlc}>6.5 \%$ and/or a 2-hour plasma glucose $>200 \mathrm{mg} / \mathrm{dL}$ using OGTT [31] Prediabetes was defined as having a fasting glucose between 100-125 mg/dL (impaired fasting glucose) and/or a 2-hour plasma glucose between 140-199 mg/dL using OGTT (impaired glucose tolerance) and/or an HbAlc between 5.7-6.4\% [31]. 
IR was determined using HOMA-IR, calculated as follows: [insulin $0^{\prime}(\mathrm{mU} / \mathrm{l}) \times$ glucose $\left.0^{\prime}(\mathrm{mmol} / \mathrm{l})\right] / 22.5$ [39] .

\section{Statistical analysis}

Distributions of continuous data were tested for normality by histograms and by the Kolmogorov-Smirnov test. Variables with a skewed distribution were transformed to a logarithmic scale and reevaluated for normality.

The unpaired Student's t-test or Mann-Whitney-U-test was used to determine differences between 2 groups, with Bonferroni adjustments for multiple comparisons. Data are expressed as mean \pm standard deviation (SD) or median [minimum-maximum]. Differences in distributions of categorical data were evaluated by $\chi^{2}$ or Fisher Exact test and expressed as percentages. Pearson correlation analysis was performed to test the link between serum magnesium and HOMA-IR. Stepwise logistic regression analysis was performed to assess the strength and independency of associations. First, the regression analysis was performed using a backward logistic regression method with and without serum magnesium included. Since serum magnesium was not included in this model for the prediction of HOMA-IR but we aimed at investigating its predictive capacities, the predictive variables were included in a new regression analysis together with serum magnesium using an ENTER method. To evaluate the influence of magnesium, the probabilities of both models were compared using ROC analysis. A two-tailed $\mathrm{p}<0.05$ was considered significant.

Ultimately, the probabilities that were obtained after the LR regression analyses were used to perform a partial correlation analysis between HOMA-IR and magnesium serum, corrected for confounding factors.

HOMA-IR was used as a surrogate variable for IR. A cut-off point was defined to divide the population in patients with a higher versus a lower insulin sensitivity.

There is no consensus for a cut-off point for HOMA-IR worldwide and this cut-off value differs between the different races. A cut-off point for a Belgian population has not been defined yet [28] Receiveroperating characteristics curves (ROC) were used to determine the HOMA-IR value with the highest combined sensitivity and specificity for metabolic syndrome (featured by IR) as state variable. This value was used as a cut-off point for IR in our Belgian population. 22.

Data were analyzed using SPSS (SPSS Inc., Chicago, USA) version

\section{Results}

\section{Population}

The population predominantly existed of Caucasians (86\%) with a mean age of $44.6 \pm 13.5$ years. Most subjects were female (70.7\%) amongst whom $23.2 \%$ were in a postmenopausal state.

Patients had a mean BMI of $36.1 \pm 7.0 \mathrm{~kg} / \mathrm{cm}^{2}$ and $82 \%$ were obese. The mean waist circumference was $107 \pm 15 \mathrm{~cm}$ in women and $117 \pm$ $17 \mathrm{~cm}$ in men. The total mean total cholesterol was $210 \pm 40 \mathrm{mg} / \mathrm{dl}$ and $65 \%$ of the patients had hypertension or were treated with antihypertensive therapy. Fifty-one percent of the patients were diagnosed with metabolic syndrome. Seventy-one percent of the patients met the criteria for prediabetes. Eighteen percent of the population had T2DM. The mean HbA1c in the entire population was $6.0 \pm 1.5 \%$. The mean HOMA-IR value was $4.2 \pm 3.8$.

In the entire population, serum magnesium averaged $1.9 \pm 0.2$ $\mathrm{mg} / \mathrm{dl}$ and $6.1 \%$ of the patients were diagnosed with hypomagnesaemia. When analyzing both groups separately, $3.4 \%$ of the obese patients had hypomagnesemia and $18.2 \%$ of the individuals with diabetes mellitus.

\section{Cut-off point for HOMA-IR}

The HOMA-IR value of 2.82 had the highest combined specificity (0.609) and sensitivity (0.749) and was used as cut-off point in our study population (Figure 2). This cut-off value is in line with previously reported HOMA-IR values pointing to insulin resistance so from now on used to define IR throughout this paper. Fifty-seven per cent of the population had a HOMA-IR value above the cut-off point.

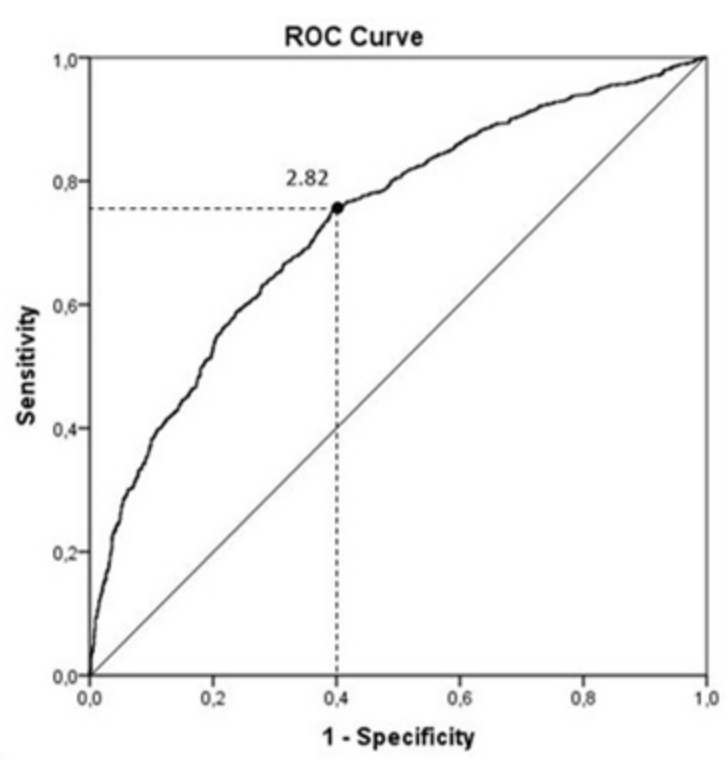

Figure 2: ROC-curve to define the HOMA-IR cut-off point for insulin resistance in Western population 2 of obese patients and patients with T2DM. HOMA-IR was plotted against metabolic syndrome as a 3 state variable of insulin resistance. The best results were obtained with a HOMA-IR of 2.82 (sensitivity 4 of 0.749 and specificity of 0.609 ). The area under the curve (AUC) was 0.733 .

\section{Characterization of insulin resistant patients}

Patients with IR were compared to those with normal insulin sensitivity. Amongst others, the following parameters significantly differed between the insulin resistant and the non-insulin resistant group (Table 1): gender $(\mathrm{p}<0.001)$, age $(\mathrm{p}<0.001)$, BMI $(\mathrm{p}<0.001)$, waist $(\mathrm{p}<0.001)$, hypertension $(\mathrm{p}<0.001)$, metabolic syndrome $(\mathrm{p}<0.001)$, serum $\mathrm{Mg}^{2+}(\mathrm{p}<0.001)$, fasting glucose $(\mathrm{p}<0.001)$, glucose $120^{\prime}$ in OGTT $(\mathrm{p}<0.001)$, HbA1c $(\mathrm{p}<0.001)$ and T2DM $(\mathrm{p}<0.001)$. Factors that were determined in at least $50 \%$ of the population and significantly differed between both groups were selected for further logistic regression analysis. 
Citation: $\quad$ Milbouw S, Verhaegen J, Verrijken A, Schepens T, de Winter BY, et al. (2017) Predictors of Insulin Resistance in Obesity and Type 2

\begin{tabular}{|c|c|c|c|}
\hline \multirow[t]{2}{*}{ Variables } & \multicolumn{2}{|l|}{ Mean/Median*/Percentage } & \multirow[t]{2}{*}{ p-value } \\
\hline & HOMA-IR $<2.82(n=1161)$ & HOMA-IR $\geq 2.82(n=1561)$ & \\
\hline Gender (M) & $214(18.4 \%)$ & $382(37.3 \%)$ & $p<0.001$ \\
\hline Age (years) & $43.29( \pm 12.73)$ & $45.40( \pm 13.93)$ & $p<0.001$ \\
\hline \multicolumn{4}{|l|}{ Anthropometry } \\
\hline Weight $(\mathrm{kg})^{*}$ & $93.20(47.00-213.60)$ & $104.40(54.10-226.60)$ & $p<0.001$ \\
\hline BMI $\left(\mathrm{kg} / \mathrm{m}^{2}\right)^{*}$ & $33.50(17.80-60.90)$ & $36.80(17.30-82.50)$ & $p<0.001$ \\
\hline Waist $(\mathrm{cm})^{*}$ & $104.35 \pm 13.61$ & $115.34 \pm 15.63$ & $p<0.001$ \\
\hline Waist hip ratio* & $0.89(0.63-1.39)$ & $0.99(0.64-1.73)$ & $p<0.001$ \\
\hline VAT on $\mathrm{CT}\left(\mathrm{cm}^{2}\right)^{*}$ & $129(15-532)$ & $184(30-590)$ & $p<0.001$ \\
\hline SAT on CT $\left(\mathrm{cm}^{2}\right)$ & $510 \pm 154.51$ & $537 \pm 173.34$ & $p<0.001$ \\
\hline Obesity & $884(76.1 \%)$ & $1339(85.8 \%)$ & $p<0.001$ \\
\hline Systolic BP (mmHg) & $128.66 \pm 14.26$ & $134.93 \pm 15.75$ & 0.021 \\
\hline Hypertension & $577(48 \%)$ & $867(56.8 \%)$ & $p<0.001$ \\
\hline Metabolic syndrome & $349(30.1 \%)$ & $1040(66.6 \%)$ & $p<0.001$ \\
\hline \multicolumn{4}{|l|}{ Standard biochemical tests } \\
\hline Leucocytes $\left(\times 10^{\wedge} 9 / I\right)^{*}$ & $6.50(2.60-14.50)$ & $7.10(2.10-20.30)$ & $p<0.001$ \\
\hline $\mathrm{HDL}(\mathrm{mg} / \mathrm{dl})^{*}$ & $56(22-128)$ & $46(14-114)$ & $p<0.001$ \\
\hline Triglycerides $(\mathrm{mg} / \mathrm{dl})^{*}$ & $114(33-851)$ & $152(31-845)$ & $p<0.001$ \\
\hline Adiponectin $(\mathrm{ng} / \mathrm{ml})^{*}$ & 10679 (2870-28182) & $8606(2090-30955)$ & 0.004 \\
\hline Leptin $(\mathrm{ng} / \mathrm{ml})^{*}$ & $22.18(1.53-103.75)$ & $17.99(1.00-110.20)$ & 0.035 \\
\hline Serum creatinine $(\mathrm{mg} / \mathrm{dl})^{*}$ & $0.81 \pm 0.14$ & $0.86 \pm 0.19$ & $p<0.001$ \\
\hline Serum sodium (mmol/l) & $140.66 \pm 2.03$ & $140.57 \pm 2.18$ & 0.009 \\
\hline Serum potassium (mmol/l) & $4.17 \pm 0.29$ & $4.19 \pm 0.33$ & 0.02 \\
\hline Serum chloride $(\mathrm{mmol} / \mathrm{l})$ & $104.66 \pm 2.39$ & $103.78 \pm 2.70$ & $p<0.001$ \\
\hline Serum calcium $(\mathrm{mg} / \mathrm{dl})^{*}$ & $9.10(3.40-11.00)$ & $9.20(2.90-11.90)$ & $p<0.001$ \\
\hline Vitamin D $(\mathrm{ng} / \mathrm{ml})^{*}$ & $26(5-150)$ & $20(3-120)$ & $p<0.001$ \\
\hline \multicolumn{4}{|l|}{ Magnesium status } \\
\hline Serum magnesium $(\mathrm{mg} / \mathrm{dl})^{*}$ & $2.00(1.00-2.50)$ & $1.90(0.70-3.70)$ & $p<0.001$ \\
\hline Hypomagnesaemia & $40(3.4 \%)$ & $125(8 \%)$ & $p<0.001$ \\
\hline FE $\mathrm{Mg}^{2+}(\%)$ & $3.61(0.05-13.18)$ & $3.50(0.03-17.21)$ & \\
\hline \multicolumn{4}{|l|}{ 24h urine collection } \\
\hline Creatinine $24 \mathrm{~h}$ urine $(\mathrm{mg} / \mathrm{d})^{*}$ & $1228(80-4128)$ & $1383(73-4042)$ & $p<0.001$ \\
\hline Calcium in $24 \mathrm{~h}$ urine $(\mathrm{mg} / \mathrm{d})^{*}$ & $146.50(5.50-677.60)$ & $162.50(3.27-785.00)$ & $p<0.001$ \\
\hline Proteins in $24 \mathrm{~h}$ urine $(\mathrm{mg} / \mathrm{d})^{*}$ & $73(0-1095)$ & $59(0-3465)$ & 0.002 \\
\hline Anorganic phosphate in $24 \mathrm{~h}$ urine $(\mathrm{g} / \mathrm{d})$ & $0.90 \pm 0.34$ & $0.97 \pm 0.39$ & $p<0.001$ \\
\hline
\end{tabular}


Citation: $\quad$ Milbouw S, Verhaegen J, Verrijken A, Schepens T, de Winter BY, et al. (2017) Predictors of Insulin Resistance in Obesity and Type 2 Diabetes Mellitus - The Role of Magnesium. J Metabolic Synd 6: 235. doi:10.4172/2167-0943.1000235

Page 5 of 9

\begin{tabular}{|c|c|c|c|}
\hline Free cortisol 24h urine $(\mathrm{mg} / \mathrm{d})^{*}$ & $58(6-740)$ & $64(4-664)$ & $p<0.001$ \\
\hline \multicolumn{4}{|l|}{ Hormonal assessment } \\
\hline $\mathrm{TSH}(\mu \mathrm{u} / \mathrm{ml})^{*}$ & $1.41(0.01-27.30)$ & $1.50(0.01-35.31)$ & 0.028 \\
\hline Estradiol (pg/ml) & $40.31 \pm 44.77$ & $33.51 \pm 36.11$ & $p<0.001$ \\
\hline Progesterone (ng/ml) & $1.18 \pm 2.57$ & $0.87 \pm 2.14$ & $p<0.001$ \\
\hline Testosterone (nmol/l) & $2.99 \pm 4.62$ & $4.53 \pm 5.17$ & $p<0.001$ \\
\hline SHBG $(\mathrm{nmol} / \mathrm{l})^{*}$ & $40(6-200)$ & $27(5-200)$ & $p<0.001$ \\
\hline Menopause & $283(30.5 \%)$ & $346(36.6 \%)$ & $p<0.001$ \\
\hline \multicolumn{4}{|l|}{ Glucose status } \\
\hline Glucose 0' in OGTT(mg/dl) & $83.50 \pm 17.20$ & $107.04 \pm 44.65$ & $p<0.001$ \\
\hline Glucose $120^{\prime}$ in OGTT(mg/dl) & $122.02 \pm 48.45$ & $168.12 \pm 87.70$ & $p<0.001$ \\
\hline Insulin $0^{\prime}$ in OGTT $(\mu \mathrm{U} / \mathrm{ml})$ & $8.95 \pm 3.25$ & $23.20 \pm 12.45$ & $p<0.001$ \\
\hline $\mathrm{HbA} 1 \mathrm{c}(\%)^{*}$ & $5.5(4.5-13.9)$ & $6.1(4.7-13.5)$ & $p<0.001$ \\
\hline Diabetes mellitus type 2 & $79(6.8 \%)$ & $410(26.2 \%)$ & $p<0.001$ \\
\hline IGF $1(\mathrm{ng} / \mathrm{ml})^{*}$ & $170(28-560)$ & $160(29-500)$ & $p<0.001$ \\
\hline \multicolumn{4}{|c|}{ 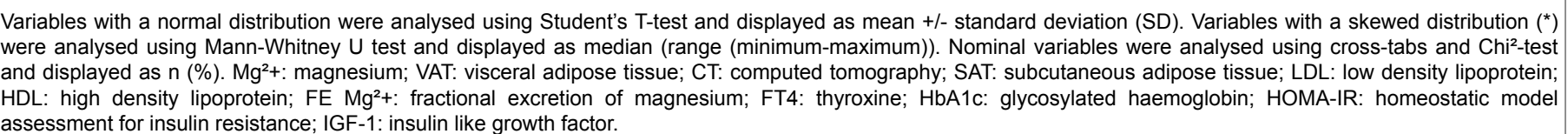 } \\
\hline
\end{tabular}

Table 1: Differences between patients with high and low HOMA-IR.

\section{Characterization of hypomagnesaemic patients}

The population was divided into two groups based on the presence or absence of hypomagnesaemia. In the hypomagnesaemic group, the median serum magnesium level was $1.6 \mathrm{mg} / \mathrm{dl}$ (range $0.70-1.70 \mathrm{mg} / \mathrm{dl}$ ) while in the normomagnesaemic group, the median serum magnesium level was $2.0 \mathrm{mg} / \mathrm{dl}$ (range 1.71-3.70 mg/dl, $\mathrm{p}<0.001$ ). Amongst others, following parameters significantly differed between both groups (Table
$2)$ : gender $(p=0.021)$, age $(p<0.001)$, hypertension $(p<0.001)$, HOMAIR $(\mathrm{p}<0.001)$, metabolic syndrome $(\mathrm{p}=0.001)$, fasting glucose $(\mathrm{p}<0.001)$, glucose $120^{\prime}$ in OGTT $(\mathrm{p}<0.001), \mathrm{HbA1c}(\mathrm{p}<0.001)$ and T2DM $(\mathrm{p}<0.001)$. BMI $(\mathrm{p}=0.643)$ and waist $(\mathrm{p}=0.064)$ did not significantly differ between normomagnesaemic and hypomagnesaemic patients.

\begin{tabular}{|c|c|c|c|}
\hline Variables & Mean/Median*/Percentage & & p-value \\
\hline & $\mathrm{Mg}^{2+}$ serum $<1,7 \mathrm{mg} / \mathrm{dl}(\mathrm{n}=176)$ & $\mathrm{Mg}^{2+}$ serum $\geq 1,7 \mathrm{mg} / \mathrm{dl}(\mathrm{n}=2658)$ & \\
\hline Gender (M) & $67(38 \%)$ & $792(30 \%)$ & 0.021 \\
\hline Age & $49.22 \pm 13.69$ & $44.35 \pm 13.37$ & $<0.001$ \\
\hline \multicolumn{4}{|l|}{ Anthropometry } \\
\hline BMI & $35.47(17.3-82.5)$ & $35.15(17.8-78.5)$ & 0.78 \\
\hline Waist & $113(70-150)$ & $109(68-193)$ & 0.056 \\
\hline Waist Hip Ratio & $1.00(0.70-1.36)$ & $0.94(0.63-1.73)$ & $<0.001$ \\
\hline VAT on $\mathrm{CT}\left(\mathrm{cm}^{2}\right)^{*}$ & $186(36-521)$ & $157(15-590)$ & 0.001 \\
\hline SAT on $\mathrm{CT}\left(\mathrm{cm}^{2}\right)$ & $478 \pm 191$ & $528 \pm 164$ & 0.005 \\
\hline Metabolic syndrome & $92(57.50 \%)$ & $1072(43.44 \%)(1072)$ & 0.001 \\
\hline
\end{tabular}


Citation: $\quad$ Milbouw S, Verhaegen J, Verrijken A, Schepens T, de Winter BY, et al. (2017) Predictors of Insulin Resistance in Obesity and Type 2 Diabetes Mellitus - The Role of Magnesium. J Metabolic Synd 6: 235. doi:10.4172/2167-0943.1000235

Page 6 of 9

\begin{tabular}{|c|c|c|c|}
\hline Hypertension & $65(37 \%)$ & 1405 (53\%) & $<0.001$ \\
\hline \multicolumn{4}{|l|}{ Standard biochemical tests } \\
\hline Cholesterol (mg/dl) & $208.25 \pm 48.71$ & $210.18 \pm 39.15$ & 0.005 \\
\hline LDL (mg/dl) & $128.91 \pm 42.92$ & $128.69 \pm 36.54$ & 0.007 \\
\hline $\mathrm{HDL}(\mathrm{mg} / \mathrm{dl})^{*}$ & $45(14-104)$ & $50(16-128)$ & $<0.001$ \\
\hline Triglycerides $(\mathrm{mg} / \mathrm{dl})^{*}$ & $158(38-875)$ & $133(31-851)$ & $<0.001$ \\
\hline Leptin $(\mathrm{ng} / \mathrm{ml})^{\star}$ & $11.94(1.00-43.17)$ & $19.84(1.21-110.20)$ & 0.001 \\
\hline Serum creatinine $(\mathrm{mg} / \mathrm{dl})$ & $0.82 \pm 0.21$ & $0.84 \pm 0.17$ & 0.008 \\
\hline Serum chloride $(\mathrm{mmol} / \mathrm{l})^{*}$ & $102.77 \pm 3.09$ & $104.25 \pm 2.55$ & $<0.001$ \\
\hline Serum calcium $(\mathrm{mg} / \mathrm{dl})^{*}$ & $9.20(7.80-10.90)$ & $9.20(2.90-11.90)$ & 0.019 \\
\hline \multicolumn{4}{|l|}{ Magnesium status } \\
\hline $\mathrm{FE} \mathrm{Mg}^{2+}(\%)^{*}$ & $4.23(0.05-15.27)$ & $3.52(0.03-17.21)$ & $<0.001$ \\
\hline Magnesium $24 \mathrm{~h}$ urine $(\mathrm{mg} / \mathrm{d})^{\star}$ & $67.00(1-243)$ & $79(1.20-273.50)$ & 0.002 \\
\hline \multicolumn{4}{|l|}{$24 \mathrm{~h}$ urine collection } \\
\hline Creatinine in $24 \mathrm{~h}$ urine $(\mathrm{mg} / \mathrm{d})^{*}$ & $1230(410-3064)$ & $1309.50(73-4128)$ & 0.001 \\
\hline Free cortisol $24 \mathrm{~h}$ urine $(\mathrm{mg} / \mathrm{d})^{*}$ & $94.50(12-598)$ & $60(4-740)$ & $<0.001$ \\
\hline \multicolumn{4}{|l|}{ Hormonal assessment } \\
\hline $\mathrm{FT} 4$ (pmol/l) & $15.09 \pm 3.36$ & $14.31 \pm 2.78$ & 0.02 \\
\hline Progesterone (ng/ml) & $0.47 \pm 0.47$ & $1.04 \pm 2.40$ & $<0.001$ \\
\hline Menopause & $44(44 \%)$ & $589(33.13 \%)$ & 0.035 \\
\hline \multicolumn{4}{|l|}{ Glucose status } \\
\hline Glucose $0^{\prime}$ in OGTT $(\mathrm{mg} / \mathrm{dl})^{*}$ & $204.50(100-350)$ & $167(80-338)$ & $<0.001$ \\
\hline Glucose 120 ' in OGTT & $232.28 \pm 123.07$ & $143.34 \pm 70.05$ & $<0.001$ \\
\hline $\mathrm{HbA1c} \%(\%)^{*}$ & $8.0(4.9-13.9)$ & $5.70(4.5-11.8)$ & $<0.001$ \\
\hline Diabetes mellitus type 2 & $90(53.89 \%)$ & $405(15.80 \%)$ & $<0.001$ \\
\hline HOMA-IR* & $5.30(0.25-55.73)$ & $3.13(0.04-52)$ & $<0.001$ \\
\hline IGF $1(\mathrm{ng} / \mathrm{ml})^{*}$ & $140(40-390)$ & $160(28-560)$ & $<0.001$ \\
\hline \multicolumn{4}{|c|}{$\begin{array}{l}\text { Variables with a normal distribution were analysed using Student's T-test and displayed as mean +/- standard deviation (SD). Variables with a skewed distribution (*) } \\
\text { were analysed using Mann-Whitney U test and displayed as median (range (minimum-maximum)). Nominal variables were analysed using cross-tabs and Chi²-tes } \\
\text { and displayed as } n(\%) \text {. } \mathrm{Mg}^{2}+\text { magnesium; VAT: visceral adipose tissue; CT: computed tomography; SAT: subcutaneous adipose tissue; LDL: low density lipoprotein } \\
\text { HDL: high density lipoprotein; FE Mgªt: fractional excretion of magnesium; FT4: thyroxine; HbA1c: glycosylated haemoglobin; HOMA-IR: homeostatic mode } \\
\text { assessment for insulin resistance; IGF-1: insulin like growth factor. }\end{array}$} \\
\hline
\end{tabular}

Table 2: Differences between patients with and without hypomagnesaemia.

\section{Correlation analysis between insulin resistance and hypomagnesaemia}

We found a significant negative correlation $(r=-0.157 ; p<0.001)$ between serum magnesium and HOMA-IR in a univariate analysis.

\section{Predictors of insulin resistance}

The logistic regression analysis revealed a predictive model consisting of the following variables: VAT, creatinine, triglycerides, waist, systolic blood pressure, estradiol, age, serum chloride, 24hproteinuria, gender and HDL as presented in Table 3. The regression analysis including serum magnesium showed that serum magnesium could not be withheld as a significant predictor for HOMA-IR $(\mathrm{p}=0.593)$ in our population. 


\begin{tabular}{|c|c|c|c|c|}
\hline \multirow{2}{*}{ Variables } & \multirow{2}{*}{$\begin{array}{l}\text { Exp } \\
\text { (B) }\end{array}$} & \multicolumn{2}{|c|}{$95 \%$ confidence interval } & \multirow[t]{2}{*}{ p-value } \\
\hline & & Lower & Upper & \\
\hline VAT on $\mathrm{CT}^{*}\left(\mathrm{~cm}^{2}\right)$ & 11.154 & 3.878 & 32.081 & $p<0.001$ \\
\hline $\mathrm{HDL}^{*}(\mathrm{mg} / \mathrm{dl})$ & 3.485 & 1.385 & 8.766 & $p=0.008$ \\
\hline Triglycerides* (mg/dl) & 3.282 & 1.66 & 6.492 & $p=0.001$ \\
\hline Serum creatinine (mg/dl) & 1.04 & 1.027 & 1.054 & $p<0.001$ \\
\hline Gender $(\mathrm{M} / \mathrm{F})$ & 1.02 & 1.011 & 1.03 & $p<0.001$ \\
\hline $\begin{array}{l}\text { Protein in } 24 \mathrm{~h} \text { urine }{ }^{*}(\mathrm{mg} / \\
24 \mathrm{~h})\end{array}$ & 0.997 & 0.994 & 1 & $p=0.038$ \\
\hline Serum chloride (mmol/l) & 0.96 & 0.948 & 0.973 & $p<0.001$ \\
\hline Age (years) & 0.929 & 0.884 & 0.98 & $p=0.007$ \\
\hline Waist $(\mathrm{cm})$ & 0.616 & 0.515 & 0.735 & $p<0.001$ \\
\hline $\begin{array}{l}\text { Systolic blood pressure } \\
(\mathrm{mmHg})\end{array}$ & 0.536 & 0.362 & 0.794 & $p=0.002$ \\
\hline Estradiol (pg/ml) & 0.091 & 0.026 & 0.319 & $p<0.001$ \\
\hline Serum $\mathrm{Mg}^{2+}(\mathrm{mg} / \mathrm{dl})$ & 2.299 & 0.108 & 48.721 & $P=0.593$ \\
\hline
\end{tabular}

Variables with skewed distribution $\left(^{*}\right)$ : logarithmic function was used. VAT: visceral adipose tissue; CT: computed tomography; HDL: high density lipoprotein; M/F: male/female.

Table 3: Multivariate logistic regression: predictive variables for HOMA-IR.

\section{Partial correlation analysis}

A new correlation analysis between HOMA-IR and serum magnesium was performed in which we corrected for the predictors of HOMA-IR as identified in the regression analysis. After correction for these predictors, a significant negative correlation between HOMA-IR and serum magnesium remained $(r=-0.085 ; \mathrm{p}<0.001)$ indicating that serum magnesium does play a role in IR although the effect is too small to be confirmed in a regression model.

\section{Discussion}

This study showed an association between hypomagnesaemia and IR in a large representative sample of an obesity clinic, including all obese subjects and not only those suspected of insulin resistance. However, we could not prove that hypomagnesemia served as an independent risk factor for IR.

In our population of obese patients and patients with T2DM, hypomagnesaemia was associated with higher HOMA-IR values. This association was confirmed by a significant negative correlation between serum magnesium and HOMA-IR, indicating that patients with lower serum magnesium are more insulin resistant and vice versa. Hypomagnesaemic patients also suffered more from metabolic syndrome and T2DM and had increased VAT on CT compared to patients without hypomagnesaemia. Patients with T2DM had more often hypomagnesaemia and higher HOMA-IR values compared to non-T2DM obese patients. Serum magnesium levels were significantly lower in IR patients compared to non-IR patients.

In this study, we propose a cut-off value for HOMA-IR in a Belgian population. Although HOMA-IR is not the gold standard for assessment of insulin sensitivity, it is a clinically useful index used in many studies [39]. In Western populations the HOMA-IR cut-off value for insulin resistance varies between 2.0 and 3.8 [29] and in a nonCaucasian population, the HOMA-IR cut-off value approximates 2.5 [30]. In the present study, a ROC-analysis was performed in which the presence of the metabolic syndrome was used as a proxy of IR. A HOMA-IR $\geq 2.82$ indicated the presence of IR, which is in range with the values found in literature.

In the entire population of our study, only $6.1 \%$ of the patients developed hypomagnesemia, which is below reported data in literature. Recently, Guerrero-Romero et al. reported an incidence of $17.1 \%, 22.4 \%$ and $24 \%$ in normal-weight, overweight and obese patients respectively [40]. These higher incidences could be explained by the fact that in that paper hypomagnesemia was defined as serum magnesium level below $1.8 \mathrm{mg} / \mathrm{dl}$, in contrast to the present study in which $1.7 \mathrm{mg} / \mathrm{dl}$ was used as a cut-off to define hypomagnesemia. And indeed, if we re-analyze our data with a cut-off serum magnesium value of $1.8 \mathrm{mg} / \mathrm{dl}, 15,1 \%$ of the entire population is diagnosed with hypomagnesemia: $11.5 \%$ of the overweight and obese patients and $32.6 \%$ of the patients with DM2, which is more in line with the Guerrero-Romero study and to studies performed in patients with DM2 (14\% to $48 \%$ ) [18-20]. Also, racial differences in serum magnesium levels have been reported. It appeared that white Canadian women develop less frequently hypomagnesemia compared to South Asian women [41]. As most patients in our study were Caucasians, the incidence of hypomagnesemia might be lower compared to studies in which non-Caucasian patients were included.

In the present study, $18 \%$ of the obese and overweight patients met the criteria for T2DM, which is in line with other reports on the prevalence of T2DM in overweight and obesity. In a study of Vinci Guerra et al., T2DM was present in $14 \%$ of the patients in an obese population [42]. In the APNA study, the prevalence of T2DM in overweight and obesity was 11.5 and $25.2 \%$ respectively [43], while in the OBEDIA study, the prevalence was higher (17.8\% for overweight and $34.8 \%$ for obesity) [44].

With the results from the present study, we substantiate the hypothesis that overweight and obesity are the strongest predictors for IR [45-47]. Our regression analysis showed that in our population VAT was the most important determinant of HOMA-IR in accordance with previous research [48]. Other important determinants (Table 3) of HOMA-IR identified in our population were triglycerides and waist circumference, in line with other data [49-54]. Other parameters that were predictive for IR in this study cohort include HDL, serum creatinine, female gender, urine protein level, serum chloride, age, systolic blood pressure and estradiol. In a recent paper, female gender was found to be a predictor of IR [55]. Proteinuria and increased serum creatinine may point to increased IR as hyperinsulinemia may induce glomerular hyperfiltration, endothelial dysfunction, and increased vascular permeability, leading to proteinuria. In turn, proteins in the tubular lumen may lead to tubulointerstitial injury and fibrosis, reflected by an increased serum creatinine [56].

T2DM patients had higher HOMA-IR values compared to obese patients, indicating that they were more insulin resistant as also shown in previous studies. Based on our results, hypomagnesaemia is associated with both higher HOMA-IR values and more VAT. In turn, VAT is associated with both hypomagnesaemia and higher HOMA-IR values. This raises the question whether the relation between 
hypomagnesaemia and the higher HOMA-IR values exists independent of the excessive presence of VAT. In addition, hypomagnesaemia is the most frequent electrolyte disorder seen in T2DM patients as was also the case in our population [18-20,57], so the association between hypomagnesaemia and higher HOMA-IR might be purely related to the higher prevalence of T2DM in hypomagnesaemia patients. To clarify these associations, further research with a longitudinal set-up is definitely warranted.

Serum magnesium could not be withheld as an independent determinant of HOMA-IR. Nevertheless, after correction for the independent determinants of HOMA-IR, including VAT and T2DM, the negative correlation between magnesium and HOMA-IR remained significant indicating that serum magnesium is independently associated with IR. From these analyses, we can conclude that hypomagnesemia is probably a consequence of IR and not the other way around.

The most important limitation of our study is the fact that it is a cross sectional study making it impossible to investigate causality of our findings. The patients who were included into our study were all followed in a tertiary hospital. Another limitation is the fact that all patients were prospectively included as part of another trial and retrospectively analyzed for the current study. Therefore, some essential information is lacking such as detailed drug and alcohol intake, two conditions that might cause hypomagnesemia [36, 58, 59]. On the other hand, our research question was to investigate if hypomagnesemia might induce metabolic disturbances and not the causative factors of hypomagnesemia. In addition, the analyses were performed in a large group of well-characterized subjects offering a big advantage, thereby using the most suitable methodologies.

\section{Conclusion}

In conclusion, our results confirm the major role of VAT and obesity in IR. However, the role of magnesium in the development of IR as suggested in literature could not be confirmed in our cohort. Based on our results, the association between serum magnesium and HOMA-IR values could not be confirmed in the logistic regression analysis. We therefore conclude that serum magnesium cannot be appointed as a determining factor for IR in this large population of obese patients and patients with T2DM. Whether hypomagnesaemia plays a role in the development of IR can only be answered by a prospective longitudinal study.

\section{Acknowledgements}

The authors who have taken part in this study declare that they have no competing interests with respect to this manuscript.

We thank the nursing staff and all patients for making this observational study possible. We also like to thank dr. Ann Verhaegen, dr. Myriam Talloen, dr. Frida Peiffer and dr. Eveline Dirinck for their contribution in the recruitment of patients.

\section{References}

1. Danaei G, Finucane MM, Lu Y, Singh GM, Cowan MJ, et al. (2011) National, regional, and global trends in fasting plasma glucose and diabetes prevalence since 1980: systematic analysis of health examination surveys and epidemiological studies with 370 country-years and 2.7 million participants. Lancet 378: 31-40.
2. Benedetti MM, Board CA (2002) The cost of diabetes Type II in Europe: the CODE-2 Study. Diabetologia 45: S1-4.

3. Williams R, Gaal LV, Lucioni C, Board CA (2002) Assessing the impact of complications on the costs of Type II diabetes. Diabetologia 45: S13-17.

4. Bagust A, Beale S (2005) Modelling EuroQol health-related utility values for diabetic complications from CODE-2 data. Health Econ 14: 217-230.

5. Gommers LM, Hoenderop JG, Bindels RJ, Baaij JH (2016) Hypomagnesemia in Type 2 Diabetes: A Vicious Circle? Diabetes 65: 3-13.

6. Agus ZS (1999) Hypomagnesemia. J Am Soc Nephrol 10: 1616-1622.

7. Chernow B, Bamberger S, Stoiko M, Vadnais M, Mills S, et al. (1989) Hypomagnesemia in patients in postoperative intensive care. Chest 95 : 391-397.

8. Ryzen E (1989) Magnesium homeostasis in critically ill patients. Magnesium 8: 201-212.

9. Marriott BP, Olsho L, Hadden L, Connor P (2010) Intake of added sugars and selected nutrients in the United States, National Health and Nutrition Examination Survey (NHANES) 2003-2006. Crit Rev Food Sci Nutr 50: 228-258.

10. Sales CH, Pedrosa LF (2006) Magnesium and diabetes mellitus: their relation. Clin Nutr 25: 554-562.

11. Alghamdi SMG, Cameron EC, Sutton RAL (1994) MagnesiumDeficiency - Pathophysiologic and Clinical Overview. American Journal of Kidney Diseases 24: 737-752.

12. Atsmon J, Dolev E (2005) Drug-induced hypomagnesaemia : scope and management. Drug Saf 28: 763-788.

13. Takaya J, Higashino H, Kobayashi Y (2004) Intracellular magnesium and insulin resistance. Magnes Res 17: 126-136.

14. Günther $\mathrm{T}$ (2011) Hypomagnesemia, obesity and inflammatory cytokines. Magnes Res 24: 19-20.

15. Nielsen FH (2010) Magnesium, inflammation, and obesity in chronic disease. Nutr Rev 68: 333-340.

16. Van Gaal LF, Mertens IL, De Block CE (2006) Mechanisms linking obesity with cardiovascular disease. Nature 444: 875-80.

17. Dandona P, Aljada A, Bandyopadhyay A (2004) Inflammation: the link between insulin resistance, obesity and diabetes. Trends Immunol 25: 4-7.

18. Barbagallo M, Bella, Brucato V, Angelo DD, Damiani P, et al. (2013) Serum ionized magnesium in diabetic older persons. Metabolism.

19. Kauffman RP, Tullar PE, Nipp RD, Castracane VD (2011) Serum magnesium concentrations and metabolic variables in polycystic ovary syndrome. Acta Obstet Gynecol Scand 90: 452-458.

20. Sheehan JP (1991) Magnesium deficiency and diabetes mellitus. Magnes Trace Elem 10: 215-9.

21. Pham PC, Pham PM, Pham SV, Miller JM, Pham PT (2007) Hypomagnesemia in patients with type 2 diabetes. Clin J Am Soc Nephrol 2: 366-373.

22. Dasgupta A, Sarma D, Saikia UK (2012) Hypomagnesemia in type 2 diabetes mellitus. Indian J Endocrinol Metab 16: 1000-1003.

23. Eibl NL, Kopp HP, Nowak HR, Schnack CJ, Hopmeier PG, et al. (1995) Hypomagnesemia in type II diabetes: effect of a 3-month replacement therapy. Diabetes Care 18: 188-192.

24. Leeuw ID, Engelen W, Block CD, Gaal LV (2004) Long term magnesium supplementation influences favourably the natural evolution of neuropathy in Mg-depleted type 1 diabetic patients (T1dm). Magnes Res 17: 109-114.

25. Chutia H, Lynrah KG (2015) Association of Serum Magnesium Deficiency with Insulin Resistance in Type 2 Diabetes Mellitus. J Lab Physicians 7: 75-78.

26. Moran MR, Romero FG (2011) Insulin secretion is decreased in nondiabetic individuals with hypomagnesaemia. Diabetes Metab Res Rev 27: 590-596.

27. de Souza ESML, Cruz T, Rodrigues LE, Ladeia AM, Bomfim O, et al. (2014) Magnesium replacement does not improve insulin resistance in 
Citation: $\quad$ Milbouw S, Verhaegen J, Verrijken A, Schepens T, de Winter BY, et al. (2017) Predictors of Insulin Resistance in Obesity and Type 2 Diabetes Mellitus - The Role of Magnesium. J Metabolic Synd 6: 235. doi:10.4172/2167-0943.1000235

Page 9 of 9

patients with metabolic syndrome: a 12-week randomized double-blind study. J Clin Med Res 6: 456-462.

28. Ghasemi A, Tohidi M, Derakhshan A, Hasheminia M, Azizi F, et al. (2015) Cut-off points of homeostasis model assessment of insulin resistance, beta-cell function, and fasting serum insulin to identify future type 2 diabetes: Tehran Lipid and Glucose Study. Acta Diabetol.

29. Gayoso-Diz P, González AO, Rodriguez-Alvarez MX, Gude F, García F, et al. (2013) Insulin resistance (HOMA-IR) cut-off values and the metabolic syndrome in a general adult population: effect of gender and age: EPIRCE cross-sectional study. BMC Endocr Disord 13.

30. Ziaee A, Esmailzadehha N, Oveisi S, Ghorbani A, Ghanei L (2015) The threshold value of homeostasis model assessment for insulin resistance in Qazvin Metabolic Diseases Study (QMDS): assessment of metabolic syndrome. J Res Health Sci 15: 94-100.

31. A.D. Association (2015) Classification and diagnosis of diabetes. Diabetes Care 38 Suppl S8-S16.

32. Blanchard A, Bockenhauer D, Bolignano D, Calo LA, Cosyns E, et al. (2017) Gitelman syndrome: consensus and guidance from a Kidney Disease: Improving Global Outcomes (KDIGO) Controversies Conference. Kidney Int 91: 24-33.

33. Groenestege WM, Thebault S, Wijst JV, van den Berg D, Janssen D, et al. (2007) Impaired basolateral sorting of pro-EGF causes isolated recessive renal hypomagnesemia. J.Clin.Invest 117: 2260-2267.

34. Del Gobbo LC, Song Y, Poirier P, Dewailly E, Elin RJ, et al. (2012) Low serum magnesium concentrations are associated with a high prevalence of premature ventricular complexes in obese adults with type 2 diabetes. Cardiovasc Diabetol 11.

35. Lameris AL, Monnens LA, Bindels RJ, Hoenderop JG (2012) Druginduced alterations in Mg2+ homoeostasis. Clin Sci (Lond) 123: 1-14.

36. Ledeganck KJ, De Winter BY, den Driessche AV, Jürgens A, Bosmans JL, et al. (2014) Magnesium loss in cyclosporine-treated patients is related to renal epidermal growth factor downregulation. Nephrol Dial Transplant 29: 1097-1102.

37. Ledeganck KJ, Boulet GA, Bogers JJ, Verpooten GA, De Winter BY (2013) The TRPM6/EGF pathway is downregulated in a rat model of cisplatin nephrotoxicity. PLoS One 8.

38. Alberti KG, Eckel RH, Grundy SM, Zimmet PZ, Cleeman JI, et al. (2009) Harmonizing the metabolic syndrome: a joint interim statement of the International Diabetes Federation Task Force on Epidemiology and Prevention; National Heart, Lung, and Blood Institute; American Heart Association; World Heart Federation; International Atherosclerosis Society; and International Association for the Study of Obesity. Circulation 120: 1640-1645.

39. Matthews DR, Hosker JP, Rudenski AS, Naylor BA, Treacher DF, et al. (1985) Homeostasis model assessment: insulin resistance and beta-cell function from fasting plasma glucose and insulin concentrations in man. Diabetologia 28: 412-419.

40. Romero FG, Garcia AF, Guerrero SS, Simental-Mendia LE, Moran MR(2016) Obesity and hypomagnesemia. Eur J Intern Med 34: 29-33.

41. Bertinato J, Xiao CW, Ratnayake WM, Fernandez L, Lavergne C, et al. (2015) Lower serum magnesium concentration is associated with diabetes, insulin resistance, and obesity in South Asian and white Canadian women but not men. Food Nutr Res 59.
42. Vinciguerra F, Baratta R, Farina MG, Tita P, Padova G, et al. (2013) Very severely obese patients have a high prevalence of type 2 diabetes mellitus and cardiovascular disease. Acta Diabetol 50: 443-449.

43. Martin-Rodriguez E, Guillen-Grima F, Marti A, Brugos-Larumbe A (2015) Comorbidity associated with obesity in a large population: The APNA study. Obes Res Clin Pract 9: 435-447.

44. Gomis R, Artola S, Conthe P, Vidal J, Casamor R, et al. (2014) [Prevalence of type 2 diabetes mellitus in overweight or obese outpatients in Spain. OBEDIA Study]. Med Clin (Barc) 142: 485-492.

45. Günther $\mathrm{T}(2010)$ The biochemical function of $\mathrm{Mg}^{2}+$ in insulin secretion, insulin signal transduction and insulin resistance. Magnes Res 23: 5-18.

46. Mlinar B, Marc J, Janez A, Pfeifer M (2007) Molecular mechanisms of insulin resistance and associated diseases. Clin Chim Acta 375: 20-35.

47. O'Rahilly S (2002) Insights into obesity and insulin resistance from the study of extreme human phenotypes. Eur J Endocrinol 147: 435-441.

48. Lin KH, Liou TL, Hsiao LC, Hwu CM (2011) Clinical and biochemical indicators of homeostasis model assessment-estimated insulin resistance in postmenopausal women. J Chin Med Assoc 74: 442-447.

49. Zheng S, Shi S, Ren X, Han T, Li Y, et al. (2016) Triglyceride glucose-waist circumference, a novel and effective predictor of diabetes in first-degree relatives of type 2 diabetes patients: cross-sectional and prospective cohort study. J Transl Med 14.

50. Bonneau GA, Pedrozo WR, Berg G (2014) Adiponectin and waist circumference as predictors of insulin-resistance in women. Diabetes Metab Syndr 8: 3-7.

51. Andersson DP, Wahrenberg H, Toft E, Qvisth V, Löfgren P, et al. (2014) Waist circumference to assess reversal of insulin resistance following weight reduction after bariatric surgery: cohort and cross-sectional studies. Int J Obes (Lond) 38: 438-443.

52. Sasaki R, Yano Y, Yasuma T, Onishi Y, Suzuki T, et al. (2016) Association of Waist Circumference and Body Fat Weight with Insulin Resistance in Male Subjects with Normal Body Mass Index and Normal Glucose Tolerance. Intern Med 55: 1425-1432.

53. CJ Glueck, Khan NA, Umar M, Uppal MS, Ahmed W, et al. (2009) Insulin resistance and triglycerides. J Investig Med 57: 874-881.

54. Kim-Dorner SJ, Deuster PA, Zeno SA, Remaley AT, Poth M (2010) Should triglycerides and the triglycerides to high-density lipoprotein cholesterol ratio be used as surrogates for insulin resistance? Metabolism 59: 299-304.

55. Magri CJ, Fava S, Galea J (2016) Prediction of insulin resistance in type 2 diabetes mellitus using routinely available clinical parameters. Diabetes Metab Syndr 10: S96-S101.

56. Zhang X, Lerman LO (2016) The metabolic syndrome and chronic kidney disease. Transl Res.

57. Kurstjens S, Baaij JH, Bouras H, Bindels RJ, Tack CJ, et al. (2017) Determinants of hypomagnesemia in patients with type 2 diabetes mellitus. Eur J Endocrinol 176: 11-19.

58. Elisaf M, Merkouropoulos M, Tsianos EV, Siamopoulos KC (1995) Pathogenetic mechanisms of hypomagnesemia in alcoholic patients. J Trace Elem Med Biol 9: 210-214.

59. Lajer H, Daugaard G (1999) Cisplatin and hypomagnesemia. Cancer Treat.Rev. 25: 47-58. 